\title{
Działalność władz miasta oraz towarzystw społecznych w walce z gruźlicą we Wrocławiu w latach 1919-1933 (wybrane aspekty)
}

Słowa kluczowe: towarzystwa, gruźlica, Wrocław (Breslau), choroba społeczna

Zagadnienie gruźlicy płuc jako problemu społecznego we Wrocławiu w Republice Weimarskiej w latach 1919-1933 dotyczy szczególnie istotnych spraw, m.in. zdrowia ludzi oraz zagrożeń, jakie niosła ze sobą choroba. Tuberkuloza należała do szczególnie niebezpiecznych schorzeń w ówczesnej Europie. Celem niniejszego artykułu jest przedstawienie działań podejmowanych przez władze miasta oraz towarzystwa społeczne, których zadaniem było ograniczenie rozprzestrzeniania się gruźlicy we Wrocławiu w okresie Republiki Weimarskiej. Artykuł jest przyczynkiem do zbadania omawianego zagadnienia. Podstawą źródłową niniejszego tekstu są Akta Miasta Wrocławia z Archiwum Państwowego we Wrocławiu, dotyczące m.in. spraw zdrowia, a także działalności towarzystw społecznych, oraz materiały znajdujące się w Bibliotece Uniwersytetu Wrocławskiego ${ }^{1}$. W tym miejscu należy zaznaczyć, że wykorzystane w tekście źródła mają charakter niekom-

\footnotetext{
${ }^{1}$ Artykuł jest fragmentem pracy magisterskiej N. Kotrys, Gruźlica płuc jako problem społeczny Wrocławia w czasach Republiki Weimarskiej (1919-1933) napisanej pod kierunkiem dr hab. Joanny Nowosielskiej-Sobel. Praca została obroniona w 2016 r. w Instytucie Historycznym Uniwersytetu Wrocławskiego.
} 
pletny, wybrakowany, przez co trudno jest wskazać środki finansowania poszczególnych organizacji walczących z gruźlicą we Wrocławiu oraz wykazać ich podległość administracyjną̨2.

Gruźlica (z języka łacińskiego tuberculosis), inaczej nazywana suchotami, należy do chorób zakaźnych ludzi oraz zwierząt. Powodują ją bakterie należące do gatunku mycobacterium tuberculosis, czyli prątki gruźlicy ${ }^{3}$. Choroba najczęściej atakowała płuca, jednak występowały też gruźlice innych narządów ${ }^{4}$. Zarażenie tuberkulozą zachodzi drogą kropelkową przez kontakt z innymi ludźmi bądź przez spożywanie zakażonego mleka zwierzęcego. Gruźlica to choroba społeczna. Dotykała głównie ludzi najuboższych i niedożywionych, choć występowała we wszystkich warstwach społecznych $^{5}$. Prątki były odporne na wysuszenia i mogły długo przeżywać w kurzu. W okresie romantyzmu tuberkuloza stała się „modna”, bo wtedy przez twórczość pisarzy i malarzy dokonano mitologizacji gruźlicy ${ }^{6}$. Choroba ta robiła „wyjątkowe wrażenie” ze względu na sposób występowania oraz na swoją formę. Dotykała ludzi młodych, dla których życie dopiero się zaczynało. Najczęściej była wyrokiem śmierci. Opisywana choroba nie była niczym mistycznym, nierealnym, lecz rzeczywistym zagrożeniem dla życia ludzkiego. Dopiero po wojnach napoleońskich zaczęto traktować gruźlicę jako chorobę masową oraz społeczną ${ }^{7}$ W latach 70 . XIX w. umierał na nią co

${ }^{2}$ Warto $\mathrm{w}$ tym miejscu zwrócić uwagę na wybrane publikacje dotyczące walki z gruźlicą: M. Migała, Rozwój terapii balneoklimatycznej na Górnym Ślasku w aspekcie leczenia gruźlicy (druga połowa XIX i pierwsza połowa XX wieku), Opole 2009; E. Dzięciołowska-Baran, A. Gawlikowska-Sroka, Gruźlica - niekończaca się opowieść, „Annales Academiae Medicae Stetinensis Roczniki Pomorskiej Akademii Medycznej w Szczecinie” 2013, R. 59, nr 2; A. Kuźmińska, Koncepcja profilaktyki chorób zakaźnych $i$ jej realizacja do końca XIX w., [w:] Człowiek, natura, kultura - studia z historii $i$ antropologii medycyny i farmacji społecznej, „Studia Humanistyczne Wydziału Farmaceutycznego Akademii Medycznej we Wrocławiu” 2009, t. 2; K. Mączyńska, M. Mączyński, Penicyliny. Historia odkrycia i pierwsze zastosowanie, [w:] B. Płonka-Syroka, A. Syroka (red.), Leczyć, uzdrawiać, pomagać. Studia z dziejów kultury medycznej, t. 11, Wrocław 2007; Z. Zwolska, Robert Koch twórca bakteriologii chorób zakaźnych, Gdańsk 2006; Z. Moskwa, Zarys historii leczenia grúlicy płuc, Warszawa 1987; H. Bynum, Spitting Blood: The history of tuberculosis, Oxford 2012; C.W. McMillen, Discovering Tuberculosis: A Global History, 1900 to the Present, Yale 2015.

${ }^{3}$ Z. Otałęga (red.), Encyklopedia biologiczna, t. 5, Kraków 1998, s. 140.

${ }^{4}$ J. Komender, M.J. Mossakowski, T. Orłowski, K. Ostrowski, W. Rudowski, A. Trzebski (red.), Wielki Stownik Medyczny, Warszawa 1996, s. 435.

${ }^{5}$ Z. Otałęga (red.), dz. cyt., s. 141.

${ }^{6} \mathrm{O}$ gruźlicy jako temacie literackim więcej w publikacji: M. Szubert, Żyjacc w cieniu śmierci... Kulturowy obraz gruźlicy, Wrocław 2011.

${ }^{7}$ M. Migała, dz. cyt., s. 42. 
Działalność władz miasta oraz towarzystw społecznych w walce z gruźlicą...

czwarty mieszkaniec Europy ${ }^{8}$. Choroba zbierała największe żniwa od XIX w., czyli od czasu szczególnego uprzemysłowienia i rozwoju małych miast i przekształcenia ich w ogromne aglomeracje. Stała się wtedy realnym zagrożeniem dla społeczeństwa. Rozwój przemysłu, tworzenie się skupisk robotniczych, a w konsekwencji problem przeludnienia i nędzy wpływały na intensywność występowania choroby ${ }^{9}$.

Do końca XIX w. naukowcy oraz lekarze byli bezradni wobec rozprzestrzeniającej się gruźlicy. Jednak w 1882 r. bakteriolog Robert Koch $^{10}$ dokonał przełomu w dziedzinie epidemiologii. Odkrył prątki gruźlicy i udowodnił, że można nimi zarażać zwierzęta. Dokonanie naukowca uważa się za przełom na skalę światową. Kolejnymi krokami $\mathrm{w}$ walce z rozwojem gruźlicy była m.in. działalność Carla Forlanina ${ }^{11}$, który zastosował pierwszą sztuczną odmę do leczenia gruźlicy, czy też Alberta Calmetta ${ }^{12}$ i Camille'a Guérina ${ }^{13}$, którzy w 1921 r. przygotowali szczepionkę $\mathrm{BCG}^{14}$, mającą zabezpieczać organizm przed prątkami. Jednak dopiero w 1944 r., dzięki zastosowaniu szczepionki przeciwgruźliczej oraz antybiotyków (streptomycyny) przez Selmana Waksmana $^{15}$, tuberkuloza stała się chorobą wyleczalną, a co najważniejsze

${ }^{8}$ T.M. Zielonka, Epidemiologia gruźlicy w Polsce i na świecie w dawnych czasach, [w:] H. Dusińska (red.), Walka z gruźlica u ludzi i zwierzat w Polsce. Stulecie pierwszego polskiego laboratorium pratka, Rudka 1912-2012, Warszawa 2012, s. 42.

${ }^{9}$ M. Migała, dz. cyt., s. 43.

${ }^{10}$ R. Koch (1843-1910) - niemiecki lekarz, twórca nowoczesnej bakteriologii i nauki o chorobach zakaźnych. Odkrył i opisał wiele bakterii chorobotwórczych, m.in. laseczki wąglika, gronkowca, zarazek gruźlicy (prątek Kocha), przecinkowca cholery. W $1905 \mathrm{r}$. otrzymał Nagrodę Nobla za badania nad grú́licą. Por. R. Koch [hasło w:] Z. Otałęga (red.), Encyklopedia biologiczna, T. 5, Kraków 1998, s. 208.

${ }^{11}$ C. Forlanin (1847-1918) - internista i ftyzjatra. Był profesorem uniwersytetu w Turynie i Pawii. Jako pierwszy zaproponował zastosowanie sztucznej odmy opłucnej w leczeniu gruźlicy płuc. Po raz pierwszy użyto jej w 1888 r. Por. C. Forlanin [hasło w:] J. Wojnowski (red.), Wielka Encyklopedia PWN, t. 9, Warszawa 2002, s. 243.

12 A. Calmette (1863-1933) - bakteriolog i higienista. Uczeń L. Pasteura. Profesor w Lille. Opracował metodę leczenia dżumy specjalną surowicą. Wraz z C. Guérinem opracował skuteczną metodę szczepień przeciwgruźliczych (BCG). Por. A. Calmette [hasło w:] J. Wojnowski (red.), Wielka Encyklopedia PWN, t. 5, Warszawa 2001, s. 130.

${ }^{13}$ C. Guérin (1872-1961) - francuski bakteriolog, weterynarz. Pracował w uniwersytecie w Lille. Wraz z A. Calmettem opracował skuteczną metodę szczepienia przeciwgruźliczego. Por. C. Guérin [hasło w:] Biographicalsketch Camille Guérin (1872-1961), https://www.britannica.com/biography/Camille-Guerin [dostęp: 29.07.2018].

${ }^{14}$ BCG - Bacillus Calmette-Guérin.

15 S.A. Waksman (1888-1973) - mikrobiolog pochodzenia żydowskiego. Wyizolował aktynomycynę, czynnik bakteriobójczy, który nazwał antybiotykiem (1941). Streptomycyna (antybiotyk) wykazała skuteczność w leczeniu gruźlicy. W 1952 r. otrzymał Nagrodę Nobla. Por. S.A. Waksman [hasło w:] Z. Otołega (red.), Encyklopedia biologiczna, t. 9, Kraków 2000, s. 218-219. 
- coraz rzadziej spotykaną ${ }^{16}$. To był przełom w rozwiązywaniu problemu umieralności oraz zahamowaniu zachorowalności na gruźlicę.

Dla krajów europejskich, szczególnie uwzględniając w tym miejscu Niemcy, punktem kulminacyjnym zachorowalności na gruźlicę były lata 80 . XIX w. ${ }^{17}$ Rocznie umierało na nią dwa razy więcej ludzi niż podczas wojny francusko-pruskiej w latach $1870-1871^{18}$. Mimo tego już na początku XX w. zanotowano widoczny spadek zachorowalności oraz śmiertelności na tuberkulozę. Warto przytoczyć cytat Eugeniusza Sokołowskiego ${ }^{19}$, który w pracy pt. Proletarjacka choroba pisał: „W Niemczech np. jeszcze w 1875 r. śmiertelność z suchot przewyższała dzisiejszą naszą, sięgając do 32,5 na 10 tysięcy mieszkańców. Opatrzono się, jednak, uświadomiono sobie klęskę, a dzisiaj nie poznać tamtego. W Niemczech spadła śmiertelność z 32,5 do 17, w New-Jorku z 85 do 35 !" ${ }^{20}$. Opisane zmiany spowodowane były wzrostem wiedzy medycznej oraz poprawą opieki społecznej w państwie.

W wielu państwach europejskich w połowie XIX w. zaczęto podejmować działania mające na celu poprawę ochrony zdrowia. W przypadku Niemiec kwestie zdrowia publicznego były częścią programu państwa ${ }^{21}$. Od stanu zdrowia obywateli miał zależeć dobrobyt oraz kondycja ekonomiczna kraju. Przepisy obowiązujące w Cesarstwie Niemieckim koncentrowały się $\mathrm{w}$ głównej mierze na działaniu przeciwepidemicznym ${ }^{22}$. Szczególną uwagę zwracano na poziom higienicznosanitarny miast, dostrzegano także związek między ubóstwem a rozprzestrzenianiem chorób. Władze podejmowały też działania mające na celu poprawę systemu ochrony zdrowia publicznego. Od $1883 \mathrm{r}$. funkcjonowała ustawa o przymusowym ubezpieczeniu chorobowym,

${ }^{16}$ J. Ruffie, J.C. Sournia, Historia epidemii. Od dżumy do AIDS, tłum. B.A. Matusiak, Warszawa 1996, s. 152.

${ }_{17}$ H.J. Blobel, Die Tuberkulosesterblichkeit in den einzelnen Stadtvierteln von Breslau wahrend der Jahre 1910-1931, Breslau 1934, s. 5.

${ }^{18}$ Die Tuberkulosebekämpfung in Breslau. Von Magistrat Alexander Wosnitza, Breslau, „Das Kommunalblatt für Ehrenbeamte“, 15 Juni 1915, Berlin, nr 7, s. 1.

${ }^{19}$ E. Sokołowski (1885-?) - autor publikacji: Mór dzieci, Warszawa 1910; Nie bijmy dzieci, Warszawa 1913; Szkoła i głód jako problem społeczno-państwowy, Warszawa 1919.

${ }^{20}$ E. Sokołowski, Proletarjacka choroba, Warszawa 1911, s. 9.

${ }^{21} \mathrm{~J}$. Nosko, Zachowania zdrowotne $i$ zdrowie publiczne. Aspekty historyczno-kulturowe, Łódź 2005, s. 162.

${ }^{22}$ W. Korpalski, J. Szmytkowski, Procesy modernizacyjne w państwie pruskim i ich wptyw na ksztattowanie modelu ochrony zdrowia publicznego na ziemiach zaboru pruskiego w XIX w. na przykładzie rejencji bydgoskiej, [w:] B. Płonka-Syroka, A. Syroka (red.), Przełom nowożytny w nauce europejskiej i jego kontekst społeczno-kulturowy, „Studia z Dziejów Kultury Medycznej”, t. 8, Wrocław 2004, s. 121. 
Działalność władz miasta oraz towarzystw społecznych w walce z gruźlicą...

a od 1884 r. ustawa o nieszczęśliwych wypadkach spowodowanych w pracy ${ }^{23}$.

W walce $\mathrm{z}$ chorobami zakaźnymi, w tym $\mathrm{z}$ gruźlicą, szczególnie istotnymi ustawami były dwie: ustawa niemiecka z $1900 \mathrm{r}$. oraz ustawa pruska z $1905 \mathrm{r}^{24}$ Są one o tyle istotne, że dzięki nim obowiązkiem stało się zgłaszanie na policję przypadków zachorowań na gruźlicę płuc bądź krtani. Również dzięki tym ustawom można było izolować osoby podejrzane o zachorowania na tuberkulozę.

Przy leczeniu gruźlicy zarówno w Cesarstwie Niemieckim, jak i innych państwach Europy stosowano leczenie klimatyczno-uzdrowiskowe, będące szczególnie popularne od I poł. XIX w. Dodatkowo starano się rozbudowywać sieć poradni przeciwgruźliczych, stosowano leczenie zapadowe, czyli odmę opłucną ${ }^{25}$. Wszystko po to, by zminimalizować rozprzestrzenianie się gruźlicy oraz by wyleczyć cierpiących na tę chorobę.

Wrocław, tak jak inne miasta niemieckie, borykał się z problemem wysokiej umieralności na gruźlicę. Jednak w przeciwieństwie do takich miast, jak Berlin czy Frankfurt nad Menem, spadek zgonów spowodowanych tuberkulozą nie był tu wysoki. Jeśli chodzi o umieralność noworodków, to stolica prowincji śląskiej plasowała się na 4. miejscu wśród miast niemieckich, natomiast jeśli chodzi o zachorowania na gruźlice płuc, to zajmowała 5 . miejsce ${ }^{26}$. W $1901 \mathrm{r}$. we Wrocławiu na 10 tys. mieszkańców liczba zgonów wynosiła 32,1, a w 1913 r. już tylko 20,327. W Niemczech natomiast w tych samych latach śmiertelność spowodowana gruźlica wynosiła w 1901 r. 20,1, natomiast w 1913 r. 13,8 na 1000 mieszkańców. Powodem tego był niekorzystny, zmienny klimat ${ }^{28} \mathrm{~W}$ mieście, który wpływał negatywnie na mieszkańców, oraz

${ }^{23}$ Tamże, s. 129.

${ }^{24}$ A. Kuźmińska, Walka z epidemiami chorób zakaźnych w Europie $w$ XIX w. ze szczególnym uwzględnieniem gruźlicy, [w:] B. Płonka-Syroka (red.), Człowiek, natura, kultura - studia z historii i antropologii medycyny i farmacji społecznej, „Studia Humanistyczne Wydziału Farmaceutycznego Akademii Medycznej we Wrocławiu”, Wrocław 2010, s. 303.

${ }^{25}$ Tamże, s. 297-300.

${ }^{26}$ Die Wohnungswirtschaft der Stadt Breslau. Denkschrift des Magistrats, pod red. radnego miasta dr Fuchsa i radcy budowlanego Behrendta, Breslau 1927, s. 69.

${ }^{27}$ Die Tuberkulosebekämpfung in Breslau..., dz. cyt., s. 1.

${ }^{28}$ Średnia wysokość nad poziomem morza wynosiła $100 \mathrm{~m}$. Krajobraz jest jednolity, równinny, bezleśny, podłoże wilgotne o wysokim poziomie wód gruntowych; notuje się wysoką ilość opadów (620 mm rocznie). Przeciętne zachmurzenie jest częste. Tereny z niekorzystnymi warunkami zdrowotnymi i budowlanymi - A. Ptaszycka, Zagospodarowanie Wrocławia w latach 1945-55, [w:] J. Świątecki (red.), Wrocław. Rozwój urbanistyczny, Warszawa 1956, s. 187-190. 
fakt, że we Wrocławiu później niż w innych miastach niemieckich zaczęły działać organizacje mające na celu zwalczanie gruźlicy. Dopiero w 1905 r. powstało Śląskie Prowincjonalne Towarzystwo do Walki z Gruźlicą (Schlesische Provinzial-Verein zur Bekämpfung der Tuberkulose in Breslau $)^{29}$.

Dla porównania warto zauważyć, że od 1898 r. ${ }^{30}$ na terenie Śląska działało Narodowe Stowarzyszenie Zakładów Leczniczych w Prowincji Śląskiej (Volksheilstätten-Verein für die Provinz Schlesien), które przyczyniło się do powstania w $1904 \mathrm{r}$. Ludowego Sanatorium im. Cesarzowej Augusty Wiktorii w Kamiennej Górze (Kaiserin Auguste Viktoria-Volksheilstättezu Landeshut), zajmującego się leczeniem chorób płucnych. Jego administratorem i właścicielem od 1905 r. było oficjalnie Śląskie Prowincjonalne Towarzystwo do Walki z Gruźlicą we Wrocławiu $^{31}$. Prawdopodobnie Narodowe Stowarzyszenie Zakładów Leczniczych w Prowincji Śląskiej zostało przemianowane na Towarzystwo do Walki z Gruźlicą.

\section{Walka władz Wrocławia z gruźlicą w okresie Republiki Weimarskiej}

Za sprawy zdrowia oraz opiekę społeczną we Wrocławiu odpowiadała Komisja VI Zgromadzenia Radnych Miejskich, która w 1920 r. została przekształcona w Urząd Opieki Społecznej ${ }^{32}$. Jej praca miała na celu pomoc mieszkańcom miasta w kwestiach socjalnych, poprawe warunków życia oraz zdrowia. To w jego gestii leżało rozwiązywanie problemów związanych m.in. z gruźlicą wśród wrocławian. Trudno określić, jak wiele towarzystw Magistrat Wrocławia finansował, jednak $\mathrm{w}$ dokumentach archiwalnych potwierdza się współpraca m.in. Komisji VI z Wrocławskim Towarzystwem do Walki z Gruźlicą (Breslauer Verein zur Bekämpfung der Tuberkulose).

Władze miasta oraz np. główny inspektor miasta (Oberstadtinspektor) starali się rozwiązywać problemy budowy mieszkań. Zdawano sobie sprawę z tego, że gruźlica to „choroba mieszkaniowa”, dlatego też

\footnotetext{
${ }^{29}$ Die Tuberkulosebekämpfung in Breslau..., dz. cyt., s. 2.

${ }^{30}$ Der Volksheilstätten-Verein für die Provinz Schlesien und sein Wirken von der Gründung: 6. Juli 1898 bis auf den heutigen Tag: 6. czerwca 1904, Breslau 1904.

${ }^{31}$ W 1904 r. w Kamiennej Górze powstało Ludowe Sanatorium im. Cesarzowej Augusty Wiktorii. Naczelnym lekarzem został pochodzący z Wrocławia dr Libawski, [w:] Volksheilstätten-Verein für die Provinz Schlesien. Verwaltungs-Bericht über das Jahr 1904, Breslau 1905, s. 3, 5.

${ }^{32}$ J. Nowosielska-Sobel, G. Sobel, Dolny Ślask w latach 1918-1945, [w:] W. Wrzesiński (red.), Dolny Śląsk. Monografia historyczna, Wrocław 2006, s. 32.
} 
Działalność władz miasta oraz towarzystw społecznych w walce z gruźlicą...

próbowano zapewniać nowe lokum ludziom zgłaszanym do magistratu - tak było w przypadku osiedla w Praczach Odrzańskich ${ }^{33}$. Zdarzały się przypadki, kiedy zamieniano mieszkania na takie, które były w lepszym stanie. Zwracano uwagę na to, ilu chorych jest w stanie płacić za czynsz, i szukano im odpowiedniego lokum ${ }^{34}$. Władze miasta zlecały również odkażanie mieszkań w przypadkach, gdy ktoś z mieszkańców chorował lub podejrzewano, że cierpi na chorobę zakaźną, taką jak np. cholera, ospa, szkarlatyna czy też właśnie gruźlica płuc ${ }^{35}$.

W latach 1901-1933 we Wrocławiu wychodziło pismo „Breslauer Gemeinde Blatt”, wydawane przez magistrat miasta. Czasopismo miało charakter informacyjny. Publikowano w nim m.in. treści zgłaszanych wniosków bądź też program posiedzeń Zgromadzenia Radnych Miejskich ${ }^{36}$. Wiele zagadnień dotyczyło również kwestii związanych z gruźlicą. Pisano tam m.in. o obowiązkowym meldowaniu ludzi chorych na gruźlicę, o czym była mowa już wcześniej. W jednym z numerów poruszono kwestię problemu tuberkulozy i tego, że powinno się walczyć ze wspomnianą chorobą ${ }^{37}$. Zgodnie z ustawą pruską z dnia 4 sierpnia 1923 r., o której można dowiedzieć się z ww. publikacji, należało meldować każdy przypadek zachorowalności na tuberkulozę. Nie zgłaszano takich przypadków do urzędów policyjnych, a do przychodni przeciwgruźliczych.

Specjalna procedura meldowania wyglądała następująco: należało zgłaszać lekarzom, że ktoś jest chory na gruźlicę. Lekarze informowali o tym policję prewencyjną (Schutzpolizei) bądź też lekarzy stojących wyżej w hierarchii. Każdy kliniczny przypadek gruźlicy krtani oraz wszelkie przypadki gruźlicy płuc musiały być zgłoszone. Dodatkowo meldowano chorych z wykrytymi w ślinie prątkami gruźlicy oraz gdy według oceny lekarza pacjent powinien być zgłoszony ${ }^{38}$. Pojawiła się jednak kwestia, która podzieliła lekarzy oraz działaczy. Jedni twierdzili, że należy meldować każdy przypadek gruźlicy, drudzy natomiast uważali, że trzeba chorego zgłaszać dopiero wtedy, gdy w jego organizmie

\footnotetext{
${ }^{33}$ O osiedlu więcej w dalszej części pracy.

${ }^{34}$ Dem Städtischen Gesundheitsamt zurückgesandt (Miejski Urząd Zdrowia. Pismo do nadinspektora dr. Steinberga z dnia 25 września 1933 w sprawie sytuacji mieszkaniowej Pana Krzoka), APwW, AMW, sygn. 19145 (8585), k. 312.

${ }^{35}$ Dokładne statystyki można znaleźć w: Statistisches Jahrbuch der Stadt Breslau, Breslau 1927, s. 99; Statistisches Jahrbuch der Stadt Breslau, Breslau 1928, s. 101; Statistisches Jahrbuch der Stadt Breslau, Breslau 1931, s. 104; Statistisches Jahrbuch der Stadt Breslau, Breslau 1934, s. 84.

${ }^{36}$ H. Okólska, Wrocławski Samorzą na początku XX w., Wrocław 2004, s. 7.

${ }^{37}$ Allgemeines-Meldepflicht, „Breslauer Gemainde Blatt“ 1929, nr 6, s. 49-51.

${ }^{38}$ Tamże, s. 50.
} 
znajdują się prątki, których istnienie udowodniono. Warto jednak zwrócić uwagę, że obywatele niechętnie zgłaszali wszystkie przypadki gruźlicy, co było spowodowane ich awersją do leczenia szpitalnego i opuszczania rodzin, a w konsekwencji - przerwą w wykonywaniu pracy.

Walka z gruźlicą obejmowała leczenie przebywających w szpitalach pacjentów. $\mathrm{W}$ opisywanym okresie istniały dwa rodzaje szpitali w Republice Niemieckiej: miejskie i krajowe. Prace szpitali miejskich były wspomagane przez szpitale krajowe. Jeszcze przed I wojną światową aktywnie działano na rzecz rozbudowy szpitali, aby zwiększyć szanse chorych na wyzdrowienie. We Wrocławiu w 1903 r. funkcjonowały 22 prywatne polikliniki oraz kliniki. Szpitalem leczniczym funkcjonującym na terenie miasta był m.in. renomowany Szpital Żydowski przy obecnej al. Wiśniowej oraz ul. Sudeckiej (Israelitisches Krankenhaus, Hohenzollernstraße, obecnie al. Wiśniowa/ul. Sudecka), cały kompleks klinik Uniwersytetu Wrocławskiego (Universitäts-Kliniken, Maxstraße, obecnie ul. Tytusa Chałubińskiego) - w tamtym czasie jeden z najnowocześniejszych w mieście czy też Szpital Wszystkich Świętych (Krankenhospital Allerheiligen, Barbarakirche/ Burgfeld, obecnie pl. Jana Pawła II) ${ }^{39}$. Szczególnym rozwiązaniem, które miało poprawić leczenie ludzi cierpiących na choroby płuc, było wzniesienie w latach 1907-1908 specjalnego baraku, pawilonu, w Klinice Chorób Dziecięcych (Kinderklinik, Tiergartenstraße, obecnie ul. Marii Składowskiej-Curie). Mieli w nim przebywać najmłodsi pacjenci chorujący na gruźlicę płuc. Pawilon składał się z dwóch pokoi dla chorych, w każdym mieściło się po sześć łóżek. Dwie sale rozdzielał pokój z wyjściem na południowo-zachodni taras. Pokój dla chorych i pomieszczenie dzienne miały na całej długości ściany okna, które dostarczały światła chorym - właśnie światło miało być lekarstwem dla podopiecznych szpitala ${ }^{40}$. Interesujące było to, że w projekcie oraz $\mathrm{w}$ realizacji uwzględniono ogrzewanie podłogowe, w tamtych czasach będące niecodziennym rozwiązaniem ${ }^{41}$. Przy tworzeniu projektu pracowali nie tylko architekci, tacy jak Arthur Buchwald, Heinrich Breisigale, ale także dyrektor Kliniki prof. Adalbert Czerny ${ }^{42}$. Świadczy

${ }^{39}$ T. Kulak, Historia Wrocławia. Od twierdzy fryderycjańskiej do twierdzy hitlerowskiej, t. II, Wrocław 2001, s. 231.

${ }^{40}$ Krankenhaus für lungenkranke Kinder an der Universität Breslau, „Zentralblatt der Bauverwaltung“ 1908, t. 28, s. 373.

${ }^{41}$ Tamże.

${ }^{42} \mathrm{M}$. Wójtowicz, Kliniki Uniwersyteckie - zespół zabudowań wydziału medycznego z lat 1887-1909, [w:] J. Rozpędowski (red.), Architektura Wroctawia Gmachy, t. 4, Wrocław 1998, s. 277. 
Działalność władz miasta oraz towarzystw społecznych w walce z gruźlicą...

to o tym, jak duży wpływ miało zdanie lekarzy na wygląd placówek i leczenie. Bezpośrednio nadzorowali oni projekty budynków, które później służyły chorym. Rady i pomysły profesora Czernego znalazły swoje odzwierciedlenie w praktyce i pozytywnie wpływały na leczenie pacjentów.

Należy podkreślić, że działalność szpitali finansowanych z funduszy miejskich wspierana była pracą szpitali krajowych. Jednym z głównych szpitali we Wrocławiu, w którym przyjmowano chorych na gruźlicę, był szpital Krajowego Zakładu Ubezpieczeń (Landesversicherungsanstalt Schlesien, Höfchenstraße i Kronprinzenstraße, obecnie: pl. Ludwika Hirszfelda i ul. Gwieździsta), gdzie znajdował się oddział gruźliczy, czy też wspomniana już Klinika Chorób Dziecięcych przy ul. Marii Skłodowskiej-Curie. Chorych na gruźlicę leczono też w miejskich szpitalach, takich jak np.: Wszystkich Świętych, Wenzel-Hancke (Wenzel-Hancke Krankenhaus, Neudorfstraße, obecnie ul. Komandorska) oraz przede wszystkim w części szpitalnej w Praczach Odrzańskich (Tuberkulosenanstalt, Stabelwitzer Straße, obecnie ul. Stabłowicka) ${ }^{43}$. Leczono też w Sanatorium na Rzecz Zwalczania Gruźlicy Skóry, prowadzonym przez Dolnośląskie Prowincjonalne Towarzystwo do Walki z Gruźlicą (Heilstätte für Hauttuberkulose des Niederschlesischen Provincial vereins zur Bekämpfung der Tuberkulose), założonym 1 października $1930 \mathrm{r}^{44}$ Początkowo (w $1933 \mathrm{r}$.) liczba chorych w tym szpitalu nie była wysoka - wynosiła jedynie 153 pacjentów.

Ważnym ośrodkiem, w którym leczono chorych wrocławian, był wspomniany już Szpital Przeciwgruźliczy (Tuberkulosenanstalt, Stabelwitzer Straße, obecnie ul. Stabłowicka) w Praczach Odrzańskich, otwarty w 1920 r. Mieścił się on w byłym Zakładzie dla Ubogich i Nieuleczalnie Chorych (Armen- Und Siechenhaus, Stabelwitzer Straße, obecnie ul. Stabłowicka) oraz w hospicjum. Projekt budynku został stworzony przez Georga Müllera oraz Maxa Berga. Szpital usytuowano na terenie zalesionym i oddalonym od centrum miasta. Został on rozplanowany $\mathrm{w}$ układzie pawilonowym, co pozwalało na izolowanie chorych.

W jednym z raportów prymariusza (lekarz-ordynator) zauważono, że do placówki przyjmowano dorosłych i dzieci. W latach 1929-1930 doszło do utworzenia nowej stacji obserwacyjnej dla chorych dzieci.

${ }^{43}$ Dokładne statystyki znaleźć można w: Statistisches Jahrbuch der Stadt Breslau, Breslau 1928, s. 102-103, Statistisches Jahrbuch der Stadt Breslau, Breslau 1927, s. $100-101$.

${ }^{44}$ Statistisches Jahrbuch der Stadt Breslau 1931, Breslau 1932, s. 101. 
Zdaniem głównego lekarza Szpitala Przeciwgruźliczego w Praczach należało otworzyć tego typu stację, gdyż istniejące były przepełnione. Należy do tego dodać, że pobyt w ośrodku trwał ok. sześciu miesięcy, a w szpitalach prowadzono kursy doszkalające dla lekarzy.

Szpital Przeciwgruźliczy w Praczach Odrzańskich w 1932 r. miał w swoim posiadaniu od 250 do 275 łóżek. Pracował w nim ordynator-prymariusz oraz 5 asystentów ${ }^{45}$. Były tam dostępne wszystkie nowoczesne metody leczenia chorób płuc, gruźlicy płuc oraz gruźlicy krtani. Obok kuracji słońcem oferowano naświetlania rentgenowskie, chemioterapię oraz metody chirurgiczne. Wykonywano zabiegi odmy, zapewniano również opiekę stomatologiczną. Szpital był wyjątkowo dobrze wyposażony i przygotowany do opieki nawet nad ciężko chorymi pacjentami. Znajdował się tam gabinet do wykonywania prześwietleń, było też laboratorium. Stosowano zasadę, że najpierw leczono chorych, a następnie starano się zapobiegać rozpowszechnianiu choroby $^{46}$.

Kolejnym, równie ważnym miejscem cenionym przez pacjentów chorych na tuberkulozę było Sanatorium w Praczach Odrzańskich (Lungenheilstätte in Herrnprotsch, Stabelwitzer Straße, obecnie ul. Stabłowicka). W latach 1899-1902 wybudowano tam kompleks Zakładu dla Ubogich i Nieuleczalnie Chorych (Armen- Und Siechenhaus, Stabelwitzer Straße, obecnie ul. Stabłowicka). Składał się on z sześciu budynków głównych. Jego projektantem był Friedrich Friese ${ }^{47}$. W kolejnych latach zdecydowano się na budowę nowych zabudowań. W budynkach szpitala dla kobiet i mężczyzn mieszkało początkowo ok. 950 osób chorych umysłowo oraz ludzi przewlekle chorych ${ }^{48}$. Krótko przed I wojną światową podjęto decyzję o budowie dwóch nowych szpitali przeznaczonych dla ludzi chorych psychicznie. Po wojnie, w związku z coraz większą liczbą zachorowań na gruźlicę zdecydowano, że szpital zostanie oddany na cele leczenia ludzi chorych na tuberkulozę. Oddano je do użytku po otwarciu szpitala przeciwgruźliczego, czyli ok. 1921 r. Z myślą o ubogich stworzono ze szpitala (który początkowo miał być przeznaczony dla epileptyków) sanatorium oraz szpital przeciwgruźliczy. W budynkach można było znaleźć wszystko to,

${ }^{45}$ Bericht Über die Stadt. Heilstätte und das Pflegehaus Breslau-Herrnprotsch (Raport o mieście. Raport głównego lekarza w szpitalu w Praczach Odrzańskich z dnia 20 czerwca 1932 r. dotyczący wyglądu oraz działalności placówki), APwW, AMW, sygn. 19145 (8585), k. 271.

46 Tamże.

${ }^{47}$ J. Harasimowicz (red.), Atlas architektury Wrocławia, t. 1, Wrocław 1997, s. 139.

${ }^{48}$ Bericht Über die Stadt..., dz. cyt. 
Działalność władz miasta oraz towarzystw społecznych w walce z gruźlicą...

co było potrzebne do poprawy zdrowia: higieniczne warunki, świeże powietrze, światło oraz przestrzeń ${ }^{49}$. W południowej części budynku znajdowała się sala do leżenia. Wymienione rozwiązania oraz ich zastosowanie wpływały pozytywnie na poprawę zdrowia oraz kondycji przebywających w sanatorium gruźlików.

\section{Towarzystwo na Rzecz Ludzi Ubogich Chorujących na Choroby Płuc we Wrocławiu (Vereins zur Fürsorge für unbemittelte Lungenkranke zu Breslau E. V ${ }^{50}$}

Jednym $\mathrm{z}$ narzędzi w zwalczaniu gruźlicy przez miasto było zakładanie towarzystw do walki $\mathrm{z}$ chorobą. $\mathrm{W}$ działalność organizacji angażowali się lekarze, higieniści i społecznicy.

Towarzystwo na Rzecz Ludzi Ubogich Chorujących na Choroby Płuc we Wrocławiu powstało w $1905 \mathrm{r}^{51}$ Od początku zrzeszało wielu lekarzy oraz działaczy społecznych. Ich celem była pomoc ludziom dotkniętym chorobami płuc. Tak jak inne organizacje, towarzystwo odczuło działania I wojny światowej oraz jej konsekwencje. Mimo problemów finansowych prowadziło Leśne Sanatorium Wypoczynkowe w Osobowicach (Walderholungsstätte im Oswitzer Park, Oswitzer Straße, obecnie ul. Osobowicka) oraz organizowało konsultacje lekarskie dla osób chorych. Pielęgniarki z Towarzystwa odwiedzały chorych w domach - po każdej wizycie zdawały sprawozdania ze swoich obserwacji, po czym podejmowały kroki w celu poprawy sytuacji pacjentów ${ }^{52}$. W razie potrzeby pielęgniarki badały również dzieci chorych i oceniały, co powinno się z nimi dalej zrobić. Poza tym członkowie Towarzystwa uczyli pacjentów, jak wypluwać flegmę oraz zapewniali im środki do dezynfekcji. Towarzystwo zajmowało się również odkażaniem pomieszczeń, w których mieszkali ludzie, i dostarczaniem żywności (ze szczególnym uwzględnieniem mleka i oleju z wątroby rekina) oraz kupnem np. odzieży czy łóżek ${ }^{53}$. Prócz tego organizowano wykłady dla pacjentów i lekarzy, podczas których prelegenci tłumaczyli, w jaki sposób należy postępować w przypadku choroby. Organizowano też kursy dla pielęgniarek z prowincji.

\footnotetext{
49 „Schlesische Zeitung“ 1925, nr 36, s. 6.

50 Przez szczątkowy charakter akt nie dotarto do statutu Towarzystwa.

${ }^{51}$ Die Tuberkulosebekämpfung in Breslau..., dz. cyt., s. 2.

52 Tamże.

${ }^{53}$ Tuberkulose-Fürsorge - Träger der Tuberkulose in Breslau: Verein zur Fürsorge für unbemittelte Lungenkranke (Dokument dotyczący opieki nad gruźlikami we Wrocławiu przez Towarzystwa na Rzecz Ludzi Ubogich Chorujących na Choroby Płuc we Wrocławiu), APwW, AMW, sygn. 19192 (8532), k. 382.
} 
Towarzystwo zajmowało się prowadzeniem Leśnych Sanatoriów Wypoczynkowych na Karłowicach i Osobowicach (Walderholungsstätte in Carlowitz und Oswitz, Carlowitz i Oswitz, obecnie ul. Karłowicka i Osobowicka). Wiele osób decydowało się na powtórne wizyty w tej placówce (tab. 1). Ogólnie w latach 1917-1918 zarejestrowano 20669 pacjentów, z czego 4277 przebywało w sanatorium po raz pierwszy. Mimo że od 1921 r. mniej ludzi zgłaszało się do placówki, czego powodem były problemy finansowe Towarzystwa, nie zmienia to jednak faktu, że świadomość pacjentów oraz zainteresowanie działalnością Towarzystwa były znaczne.

Tab. 1. Towarzystwo do Opieki nad Biednymi i Chorymi na Choroby Płuc we Wrocławiu (Vereins zur Fürsorge für unbemittelte Lungenkranke zu Breslau)

\begin{tabular}{|c|c|c|c|c|c|}
\hline Lata & \multicolumn{2}{|c|}{$\begin{array}{c}\text { Liczba kuracjuszy } \\
\text { Leśnych Sanatoriów } \\
\text { Wypoczynkowych na } \\
\text { Osobowicach i Karłowicach }\end{array}$} & \multicolumn{2}{c|}{$\begin{array}{c}\text { Liczba pacjentów } \\
\text { odwiedzająca Leśne } \\
\text { Sanatoria należące } \\
\text { do Towarzystwa }\end{array}$} & $\begin{array}{c}\text { Liczba dni, } \\
\text { w których } \\
\text { korzystano } \\
\text { z sanatoriów }\end{array}$ \\
\hline & Ogółem & Pierwsza wizyta & Dzieci & Dorośli & \\
\hline $\mathbf{1 9 1 7 / 1 9 1 8}$ & 20669 & 4277 & 458 & 393 & 154 \\
\hline $\mathbf{1 9 1 8 / 1 9 1 9}$ & 25374 & 4709 & 489 & 437 & 154 \\
\hline $\mathbf{1 9 1 9 / 1 9 2 0}$ & 31333 & 7063 & 426 & 78 & 154 \\
\hline $\mathbf{1 9 2 0} / \mathbf{1 9 2 1}$ & 37727 & 8050 & & & \\
\hline $\mathbf{1 9 2 1}$ & 0 & 6171 & 520 & 125 & 147 \\
\hline $\mathbf{1 9 2 2}$ & 27344 & 5979 & 570 & 156 & 0 \\
\hline $\mathbf{1 9 2 3}$ & 26977 & 5362 & 317 & 106 & 138 \\
\hline
\end{tabular}

Źródło: Statistisches Jahrbuch der Stadt Breslau, Breslau 1922, s. 70; Statistisches Jahrbuch der Stadt Breslau, Breslau 1924, s. 64; Statistisches Jahrbuch der Stadt Breslau, Breslau 1926, s. 68.

Towarzystwo współpracowało z Niemieckim Centralnym Komitetem do Walki z Gruźlicą (Deutschen Zentralkomitee zur Bekämpfung der Tuberkulose $)^{54}$. Chciano zapewnić cierpiącym na gruźlicę opiekę, z możliwością nocowania w ośrodku. Głównym celem jednak była profilaktyka. Zły stan mieszkań, brak wentylacji i dostępu do okien wpływał na pogarszanie się stanu pacjentów ${ }^{55}$. Towarzystwo powołało również Komisję ds. Zwalczania Gruźlicy w Stanie Średnim (Ausschuß für Tuberkulose Fürsorge im Mittelstande) ${ }^{56}$.

\footnotetext{
${ }^{54}$ Tuberkulose-Fürsorge - Träger..., dz. cyt.

${ }^{55}$ Tamże.

56 Tamże.
} 
Działalność władz miasta oraz towarzystw społecznych w walce z gruźlicą...

Towarzystwo na Rzecz Ludzi Ubogich Chorujących na Choroby Płuc we Wrocławiu było prężnie działającą organizacją. Nie ograniczało się wyłącznie do organizowania pomocy lekarskiej, ale zapewniało prowadzenie sanatoriów, które odgrywały niebagatelną rolę w leczeniu chorób płuc.

\section{Leśne Sanatoria Wypoczynkowe na Karłowicach i Osobo- wicach (Walderholungsstätte in Carlowitz und Oswitz)}

Leśne Sanatoria Wypoczynkowe na Karłowicach i Osobowicach należały do Wrocławskiego Towarzystwa Opieki, później do Wrocławskiego Towarzystwa do Walki z Gruźlicą (Breslauer Verein zur Bekämpfung der Tuberkulose). Zostały otwarte ok. 1909/1910 r. ${ }^{57}$ Sanatoria były udostępniane pacjentom od połowy maja do połowy października. Miejsca były skierowane głównie do ludzi chorych na gruźlicę. Dzieci miały tam możliwość uczenia się. Z roku na rok sanatoria zyskiwały na popularności. W 1913 r. liczba pacjentów na Osobowicach wyniosła 133 osoby, a na Karłowicach $121^{58}$. Przez cały czas trwania „sesji roku”, w czasie kiedy był otwarty, ośrodek na Karłowicach przyjął 493 osoby, a na Osobowicach $-334^{59}$. Okres trwania kuracji wynosił od 6 do 7 tygodni. Jeśli chodzi o koszty leczenia, po części pokrywał je Zakład Ubezpieczeń Społecznych Prowincji Śląskiej (Landesversicherungsanstalt Schlesien) ${ }^{60}$. W sanatoriach kładziono nacisk na właściwe odżywianie oraz przebywanie na świeżym powietrzu, edukację, kąpiele słoneczne (Sonnenbad) i ćwiczenia gimnastyczne.

Działacze Towarzystwa zdawali sobie sprawę, że ludzie w ciężkim stadium choroby nadal pracowali, a środowisko mieszkaniowe było dla nich szkodliwe ${ }^{61}$. Ryzyko rosło zwłaszcza w nocy, kiedy ludzie spali w zaniedbanych mieszkaniach, dlatego też Towarzystwo oferowało noclegi na terenie kompleksu.

Do przełomu lat 1928/1929 były to jedne z nielicznych miejsc na mapie Wrocławia, gdzie skupiano się wyłącznie na opiece nad

\footnotetext{
${ }^{57}$ Data ta jest przypuszczalna. Brak pewności wynika z niekonkretnych informacji co do momentu założenia ośrodka. Opiera się ją na pierwszej informacji pojawiającej się w aktach, tj. ok. 1910 r. - Aufruf ! (Apel!, Apel do walki z gruźlicą. Wydany ok. 1910 r.), APwW, AMW, sygn. 19190 (8630), k. 51.

${ }^{58}$ Die Tuberkulosebekämpfung in Breslau..., dz. cyt., s. 3.

59 Tamże.

60 Tamże.

${ }^{61}$ Zur Bekämpfung der Tuberkulose bestehen in Breslau folgende Einrichtungen (w celu zwalczenia gruźlicy ok. 1923 r.), APwW, AMW, sygn. 19192 (8532), k. 381.
} 
gruźlikami, a jednocześnie nie miały one charakteru szpitala. Dopiero we wspomnianych latach 1928/1929 powstało specjalne osiedle dla chorujących, w którym mogli nie tylko mieszkać, ale także leczyć się. Szczególnie interesująca jest działalność pielęgniarek przy Towarzystwie do Opieki nad Biednymi i Chorymi na Choroby Płuc. Warto zwrócić uwagę, że nie pracowały one jedynie w obrębie sanatoriów, ale także wyjeżdżały do chorych, których było znacznie więcej (tab. 2). Pokazuje to, jak starano się dotrzeć do ludzi chorujących.

Tab. 2. Leśne sanatoria wypoczynkowe na Karłowicach i Osobowicach

\begin{tabular}{|c|c|c|c|c|c|c|c|}
\hline \multirow[b]{2}{*}{ Lata } & \multicolumn{2}{|c|}{$\begin{array}{c}\text { Liczba } \\
\text { kuracjuszy }\end{array}$} & \multicolumn{2}{|c|}{$\begin{array}{c}\text { Liczba } \\
\text { wykonywanych } \\
\text { badań lekarskich }\end{array}$} & \multicolumn{2}{|c|}{$\begin{array}{l}\text { Działalność } \\
\text { pielęgniarek }\end{array}$} & \multirow[b]{2}{*}{ 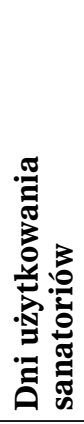 } \\
\hline & $\underset{0}{0}$ & 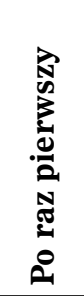 & 总 & 兽 & 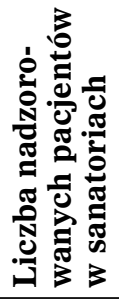 & 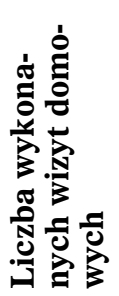 & \\
\hline $1922 / 1923$ & 27344 & 5979 & 16740 & 2996 & 2237 & 10149 & 0 \\
\hline $1923 / 1924$ & 26977 & 5362 & 16120 & 2862 & 2229 & 9371 & 138 \\
\hline $1924 / 1925$ & 25075 & 4934 & 14674 & 2511 & 2286 & 9097 & 144 \\
\hline $1925 / 1926$ & 0 & 0 & 0 & 0 & 0 & 0 & 136 \\
\hline
\end{tabular}

Źródło: Statistisches Jahrbuch der Stadt Breslau, Breslau 1926, s. 68.

\section{Wrocławskie Towarzystwo do Walki z Gruźlicą (Breslauer Verein zur Bekämpfung der Tuberkulose)}

Wrocławskie Towarzystwo do Walki z Gruźlicą zostało utworzone najprawdopodobniej w 1927 r. - zostało przekształcone z Towarzystwa na Rzecz Ludzi Ubogich Chorujących i kontynuowało jego prace ${ }^{62}$. Działal-

${ }^{62}$ Są to jedynie wnioski autorki niniejszej pracy. W 1927 r. przestały pojawiać się roczne sprawozdania Towarzystwa do Opieki nad Biednymi i Chorymi na Choroby Płuc we Wrocławiu, a pojawiły się sprawozdania z działalności Wrocławskiego Towarzystwa do Walki z Gruźlicą. Zgodnie ze wspomnianymi sprawozdaniami drugie towarzystwo zajmowało się m.in. opieką nad Leśnym Sanatorium Wypoczynkowym oraz przejęło całą działalność mającą na celu zwalczanie gruźlicy wśród mieszkańców miasta. Dodatkowo w aktach Miasta Wrocławia od 1927 r. zaczęły pojawiać się informacje na temat Wrocławskiego Towarzystwa do Walki z Gruźlicą, a przestały - te dotyczące towarzystwa powstałego $\mathrm{w} 1905 \mathrm{r}$. 
Działalność władz miasta oraz towarzystw społecznych w walce z gruźlicą...

ność Wrocławskiego Towarzystwa do Walki z Gruźlicą obejmowała: prowadzenie Sanatorium dla Dzieci w Jedlinie Zdroju (Breslauer Kindererholungsheim in Charlottenbrunn, Schönblickweg, obecnie ul. Piękna), Leśne Sanatoria Wypoczynkowe na Karłowicach i Osobowicach (Walderholungsstätte in Carlowitz und Oswitz, Carlowitz i Oswitz, obecnie ul. Karłowicka i Osobowicka) oraz osiedle dla gruźlików w Praczach Odrzańskich (Tuberkulose-Siedlung Breslau Herrnprotsch, Stabelwitzer Straße, obecnie ul. Stabłowicka) ${ }^{63}$. Towarzystwo chciało się skupić na leczeniu chorych w stanie średnim. Jego celem było polepszenie warunków mieszkaniowych, pomoc w znalezieniu pracy chorym, jeśli stara była szkodliwa dla zdrowia, kupowanie ubrań oraz intensywna opieka nad pacjentami.

O działalności Wrocławskiego Sanatorium dla Dzieci w Jedlinie Zdrój nie ma wielu informacji. Z rocznego sprawozdania za 1929/1930 r. wiadomo jednak, że cieszyło się zainteresowaniem. W ośrodku znajdowało się 80 łóżek, a od 1 kwietnia 1929 r. do 31 maja 1930 r. przyjęto 641 dzieci i wydano 25789 posiłków ${ }^{64}$. Zwracano tam uwagę na wzrost masy ciała dzieci, co miało wpłynąć na polepszenie ich zdrowia.

$\mathrm{Z}$ tego samego sprawozdania można również dowiedzieć się, że sanatorium na Osobowicach działało od 3 czerwca 1929 r. do 13 października 1929 r. Na każdego pacjenta przypadało 41,2 dnia opieki. W sumie przyjęto 305 pacjentów. Jeśli chodzi o stawkę opłat, wynosiła ona 2,5 marki za dorosłego i 1,85 za dziecko ${ }^{65}$. Rodzice dopłacali do leczenia dzieci jedynie 0,40 marki ${ }^{66}$. Ośrodek był otwarty przez 133 dni w roku.

W sprawozdaniu rocznym towarzystwa za okres 1929/1930 zaznaczono, że przyjęto 64 chorych ( 25 mężczyzn i 39 kobiet ${ }^{67}$. Kuracje dla dzieci przeprowadzano w górach, gdzie był korzystniejszy klimat niż $\mathrm{w}$ mieście ${ }^{68}$. Zarówno dzieci, jak i dorośli w średnim stanie byli

${ }^{63}$ 25. Jahresbericht Breslauer Vereins zur Bekampfung der Tuberkulose (E. V.) uber das Geschaftsjahr 1929/1930, s. 1.

${ }^{64}$ Tamże, s. 5.

${ }^{65}$ Tamże.

${ }^{66}$ Tamże.

${ }^{67}$ Tamże, s. 6.

${ }^{68}$ W 21 przypadkach kuracja została przeprowadzona w takich sanatoriach, jak: sanatorium w Praczach Odrzańskich (Lungenheilstätte in Herrnprotsch, Stabelwitzer Straße, obecnie ul. Stabłowicka) - 9 osób; w Szklarskiej Porębie (Heilstätte Moltkefels, Moltkefels-Weg, obecnie ul. Sanatoryjna) - 3 osoby; Kowalowo (Beuchler's Sanatorium, Buchberg, obecnie ul. Wałbrzyska) - 1 osoba, Sokołowie (Dr Brehmer's Heilanstalten, Brehmerplatz, obecnie ul. Różana) - 4 osoby, Kamiennej Górze (Kinderheilstätte Landeshut, Ziederstrasse, obecnie ul. Janusza Korczaka) - 1 osoba, Bukowcu (Heilstätte Buchwald, obecnie ul. Sanatoryjna) - 1 osoba, Obornikach Śląskich (Friedrichshöhe, Prausnitzerstrasse, obecnie ul. Prusicka) - 2 osoby. 
karmieni mlekiem oraz tranem. Całkowity koszt opieki nad chorymi w latach 1920/1930 wynosił 28 087,81 marek $^{69}$.

Towarzystwo zajmowało się również pomocą wrocławianom, którzy borykali się z problemami mieszkaniowymi. Interesującym przykładem może być list pani Elisabeth Scholz mieszkającej na dawnej Sternstrasse (obecnie ul. Henryka Sienkiewicza). Wyjaśnia w nim swoją sytuację: nie jest już chora, lecz boryka się z innymi trudnościami. Zakazano jej przebywania $\mathrm{w}$ dotychczasowym lokum i w związku $\mathrm{z}$ tym prosi o pomoc $\mathrm{w}$ znalezieniu innego miejsca ${ }^{70}$. Wrocławianie liczyli na wsparcie Towarzystwa, które było otwarte na różne rodzaje pomocy. I otrzymywali ją, o czym może świadczyć szczególnie istotne przedsięwzięcie, jakim było stworzenie Osiedla dla Gruźlików w Praczach Odrzańskich (Tuberkulosen Siedlung in Herrnprotsch, Stabelwitzer Straße, obecnie ul. Stabłowicka). Budowa kompleksu zakończyła się w latach 1928-1929. Osada dla gruźlików była pierwszym tego typu rozwiązaniem na terenie Niemiec ${ }^{71}$. Odegrała niebagatelną rolę w walce $\mathrm{z}$ gruźlicą we Wrocławiu. Mogli tam na jakiś czas znaleźć dla siebie miejsce m.in. ludzie tacy, jak Elisabeth Scholz.

\section{Inne towarzystwa przeciwgruźlicze działające na terenie Wrocławia w latach 1919-1933}

Prócz wymienionych do tej pory organizacji należy wspomnieć również o Śląskim Prowincjonalnym Towarzystwie do Walki z Gruźlicą we Wrocławiu (Schlesische Provinzial-Verein zur Bekämpfung der Tuberkulose in Breslau) oraz o Dolnośląskim Prowincjonalnym Towarzystwie do Walki z Gruźlicą (Niederschlesischer Provinzial verein zur Bekämpfung der Tuberkulose) $)^{72}$. Odegrały one znaczącą rolę nie tylko na terenie Wrocławia, lecz także w całej prowincji śląskiej.

Śląskie Towarzystwo do Walki z Gruźlicą zajmowało się (prócz leczenia pacjentów) również leczeniem ludzi zarażonych toczniem (lupus) $)^{73}$. W aktach dotyczących opieki gruźliczej (Tuberkulosefür-

\footnotetext{
69 25. Jahresbericht Breslauer Vereins..., dz. cyt., s. 6.

70 Abschrift, aus Breslau dem 6 Juli 1932 an verein zur Bekämpfung der Tuberkulose (Odpis listu od Elisabeth Scholz do Wrocławskiego Towarzystwa do Walki z Gruźlicą z dnia 6 lipca 1932 r. z prośbą o pomoc w zmianie mieszkania), APwW, AMW, sygn. 19145 (8585), k. 267.

71 J. Harasimowicz (red.), Encyklopedia Wrocławia, Wrocław 2006, s. 713.

72 Autorka niniejszego tekstu przypuszcza, że pierwsze towarzystwo zmieniło się w drugie. Przez brak pewności postanowiono potraktować oba towarzystwa osobno.

${ }^{73}$ Lupus - Wertblatt (Fragment artykułu o nazwie ,Toczeń - instrukcja”. Zapisano, że artykuł znajduje się w gazecie „Schlesische Volkszeitung”), APwW, AMW, sygn.
} 
Działalność władz miasta oraz towarzystw społecznych w walce z gruźlicą...

sorge) znajdują się artykuły oraz dokumenty poświadczające, że Śląskie Towarzystwo do Walki z Gruźlicą wzorowało się na działaniach ośrodków i sanatoriów z innych miast niemieckich. W dokumentach znaleźć można zbiory artykułów dotyczących aktualnie opuszczonego sanatorium i szpitala w Beelitz pod Berlinem, w którym leczono choroby płuc oraz gruźlicę ${ }^{74}$.

Członkowie Towarzystwa prowadzili akcje edukacyjne $\mathrm{w}$ celu propagowania ochrony przed gruźlicą. $\mathrm{W}$ materiałach dotyczących działalności Prowincjonalnego Towarzystwa do Walki z Gruźlicą znaleźć można liczne broszury, tłumaczące, czym była gruźlica, jak z nią walczono, w jaki sposób można się było jej ustrzec, oraz materiały dla dzieci z radami, jak dbać o zdrowie, jak się odżywiać i że należy spędzać czas na świeżym powietrzu ${ }^{75}$. Rozdawali broszury, w których można było znaleźć m.in. zasady dotyczące zapobiegania gruźlicy ${ }^{76}$. Radzono m.in., aby nie pluć na podłogę, a plwociny niszczyć, podczas kaszlu zachowywać odstęp, odchodzić metr od innych i kaszleć w chusteczkę. Należało gotować mleko, jeśli mogło pochodzić ze stajni, w której zwierzęta były zarażone prątkami gruźlicy. Zalecano, aby każdy gruźlik miał swoje łóżko. Radzono, aby wzmacniać ciało przez hartowanie oraz udział w grach ruchowych i sportowych. Wskazywano również na fakt, że w przypadku zachorowania należało szybko zgłosić się do lekarza lub organizacji do walki z gruźlicą ${ }^{77}$.

Kolejna organizacja - mianowicie Dolnośląskie Prowincjonalne Towarzystwo do Walki z Gruźlicą - zajmowała się również przygotowywaniem szkoleń dla pielęgniarek. Jedno z takich spotkań odbywało się w okresie od 30 kwietnia do 9 maja 1928 r. we Wrocławiu. Jego tematami były: patologia gruźlicy, przedstawienie ryzyka zachorowalności, sprawy ubezpieczeniowe, kwestie gruźlicy w dzieciństwie, gruźlica chirurgiczna, rozbudowa lecznictwa, instrukcja doszkalająca w badaniu plwocin ${ }^{78}$ oraz izolacja gruźlików ${ }^{79}$. Szkolone kobiety miały

19139 (8579), k. 4. Toczeń to choroba, w której rozróżnia się toczeń gruźliczy, czyli gruźlicę toczniową, oraz toczeń rumieniowaty - J. Komender, M.J. Mossakowski, T. Orłowski, K. Ostrowski, W. Rudowski, A. Trzebski (red.), dz. cyt., s. 1365.

${ }^{74}$ Erfolgreiche Tuberkulosebekämpfung. Ein Bericht aus den Lungenheilstätten Beelitz (Sukcesy w zwalczaniu gruźlicy. Sprawozdanie z sanatorium zajmującego się leczeniem gruźlicy oraz chorób płuc w Beelitz, 20 sierpnia 1927 r.), tamże, k. 5.

${ }_{75}$ Gesundheit ist Lebensglück. Reichs Gesundheitswoche 1926. Ein Merkbüchlein für Jedermann, Berlin 1926, s. 23.

76 Tamże.

77 Tamże.

${ }^{78}$ Wykrztuszana wydzielina z dróg oddechowych.

${ }^{79}$ Bekämpfung der Tuberkulose (Zwalczanie gruźlicy, 14 kwietnia 1927 r.), APwW, AMW, sygn. 19139 (8579), k. 23. 
wykorzystywać nabytą wiedzę podczas pracy na terenie Śląska. Każda pielęgniarka miała obowiązek ukończenia całego kursu. Uczestnictwo było bezpłatne. Szkolenie odbywało się pod nadzorem znanych lekarzy, m.in. dr. Leichtentritta i dr. Heinzego.

Kolejny kurs, tym razem doszkalający w kwestiach gruźlicy, organizowany przez wspomniane towarzystwo, został zapowiedziany na $1929 \mathrm{r}^{80}$ Informacja o nim została umieszczona w gazecie „Schlesische Volszeitung”, w numerze 27 z 17 stycznia 1929 r. Kurs odbywał się w Kamiennej Górze i trwał dwa tygodnie. Był bezpłatny, dodatkowo uczestnikom zapewniono noclegi oraz posiłki.

Można skłaniać się ku stwierdzeniu, że zarówno we Wrocławiu, jak i w całej Prowincji Śląskiej istniała wystarczająca liczba organizacji oraz towarzystw, które walczyły z grú́licą. Świadczy o tym fakt, że w 1930 r. inspektor sejmu Prowincji Śląskiej (Landesoberinspektor) Tilch wystosował pismo ${ }^{81}$, w którym zaznaczył, że w Prowincji Śląskiej jest wystarczająco dużo organizacji do zwalczania gruźlicy, a powstające nowe będą wchodzić w kompetencje starych, co w konsekwencji może rozbić już istniejące. Chciano uniknąć rozdrobnienia organizacyjnego. Była to reakcja na powstanie w 1929/1930 r. Niemieckiego Związku Gruźliczego (Deutsche Tuberkulosen-Bund) z ramienia Niemieckiego Centralnego Komitetu do Walki z Gruźlicą (Deutsche Zentralkomitee zur Bekämpfung der Tuberkulose). Jego celem nie była wyłącznie walka z gruźlicą we Wrocławiu, ale także w całych Niemczech. Jak słusznie zauważył Tilch, nowa organizacja mogła jedynie rozbić już istniejące towarzystwa, a nie pomóc w ich rozwoju.

\section{Zakończenie}

Jedną z najczęściej występujących chorób zakaźnych okresu Republiki Weimarskiej we Wrocławiu była gruźlica. Wrocław zajmował piąte miejsce wśród dużych miast pod względem zachorowalności na tuberkulozę w Niemczech. Wysoka zapadalność oraz umieralność na omawianą chorobę spowodowana była szczególnie złym stanem mieszkań we Wrocławiu. W literaturze z epoki często pojawiało się

${ }^{80}$ Ärztliche Fortbildungskurse in der früh diagnose und Prognose der Tuberkulose (Kurs doszkalający w kwestiach zwalczania gruźlicy oraz zapobiegania we wczesnej diagnozie), 17 stycznia 1929 r., tamże, k. 97.

${ }^{81}$ Ein vertraulicher Brief, des Inspektors der schlesischen Provinz Tilcha vom 30. Januar 1930 über die Bildung neuer Organisationen und Antituberkulosegesellschaften in der Provinz Schlesien (Poufny list inspektora prowincji śląskiej Tilcha $\mathrm{z}$ dnia 30 stycznia 1930 r., dotyczący powstawania kolejnych organizacji oraz towarzystw przeciwgruźliczych na terenie Prowincji Śląskiej), tamże, k. 182. 
Działalność władz miasta oraz towarzystw społecznych w walce z gruźlicą...

określenie, że nie tylko leczyło się gruźlicę, ale także walczono z nią. Już przed I wojną światową socjaldemokraci mieli jasno określoną politykę socjalną. Po zakończeniu wojny mogli ją realizować na terenie Republiki Weimarskiej.

Władze Wrocławia miały szczególnie duży problem z walką z gruźlicą na terenie miasta. Podejmowano liczne działania mające na celu zapobieganie rozprzestrzenianiu się tej choroby oraz zminimalizowanie umieralności wśród mieszkańców. Mimo trudnej sytuacji ekonomicznej miasta władza socjaldemokratyczna wdrażała w życie politykę poprawiającą sytuację społeczną mieszkańców. Skupiano się na polepszeniu stanu mieszkań, utworzeniu szpitali, finansowano sanatorium w Praczach Odrzańskich oraz inne placówki, w których ludzie chorzy na gruźlicę mogli się leczyć. Wysiłki władz miasta dawały impuls do działania innym organizacjom oraz instytucjom, które mogły wpłynąć na poprawę życia mieszkańców Wrocławia. Nie można mówić o znacznej poprawie sytuacji mieszkaniowej, zdrowotnej i społecznej w mieście, jednak dzięki działaniom władz Wrocławia i towarzystw przeciwgruźliczych dostrzegalne stało się polepszenie warunków, w jakich żyli ludzie w stolicy Dolnego Śląska, co w konsekwencji prowadziło do zmniejszenia zachorowalności m.in. na gruźlicę.

\section{Bibliografia}

\section{Źródła archiwalne}

Archiwum Państwowe we Wrocławiu (APwW); zespó1: Akta Miasta Wrocławia (AMW).

\section{Prasa codzienna, czasopisma}

„Schlesische Zeitung” 1925, nr 36.

25. Jahresbericht Breslauer Vereins zur Bekampfung der Tuberkulose (E. V.) uber das Geschaftsjahr 1929/1930.

Allgemeines-Meldepflicht, „Breslauer Gemainde Blatt”, 10.06.1929, nr 6.

Die Tuberkulosebekämpfung in Breslau. Von Magistrat Alexander Wosnitza, Breslau, „Das Kommunalblatt für Ehrenbeamte”, 15.06.1915, Berlin, nr 7.

Krankenhaus für lungenkranke Kinder an der Universität Breslau, „Zentralblatt der Bauverwaltung” 1908, t. 28. 


\section{Źródła publikowane wydane przed 1945 r.}

Blobel H.J., Die Tuberkulosesterblichkeit in den einzelnen Stadtvierteln von Breslau wahrend der Jahre 1910-1931, Breslau 1934.

Der Volksheilstätten-Verein für die Provinz Schlesien und sein Wirken von der Gründung: 6. Juli 1898 bis auf den heutigen Tag: 6. czerwca 1904, Breslau 1904.

Die Wohnungswirtschaft der Stadt Breslau. Denkschrift des Magistrats, pod red. radnego miasta dr Fuchsa i radcy budowlanego Behrendta, Breslau 1927.

Gesundheit ist Lebensglück. Reichs Gesundheitswoche 1926. Ein Merkbüchlein für Jedermann., Berlin 1926.

Sokołowski E., Mór dzieci, Warszawa 1910.

Sokołowski E., Nie bijmy dzieci, Warszawa 1913,

Sokołowski E., Proletarjacka choroba, Warszawa 1911.

Sokołowski E., Szkoła i głód jako problem społeczno-państwowy, Warszawa 1919.

Volksheilstätten-Verein für die Provinz Schlesien. Verwaltungs-Bericht über das Jahr 1904, Breslau 1905.

Wydawnictwa statystyczne opublikowane przed 1945 r.

Statistisches Jahrbuch der Stadt Breslau 1931, Breslau 1932.

Statistisches Jahrbuch der Stadt Breslau, Breslau 1927.

Statistisches Jahrbuch der Stadt Breslau, Breslau 1928.

Statistisches Jahrbuch der Stadt Breslau, Breslau 1931.

Statistisches Jahrbuch der Stadt Breslau, Breslau 1934.

\section{Literatura wydana po 1945 r.}

Bynum H., Spitting Blood: The history of tuberculosis, Oxford 2012.

Dzięciołowska-Baran E., Gawlikowska-Sroka A., Gruźlica - niekończaca się opowieść, „Annales Academiae Medicae Stetinensis Roczniki Pomorskiej Akademii Medycznej w Szczecinie” 2013, R. 59, nr 2.

Korpalski W., Szmytkowski J., Procesy modernizacyjne w państwie pruskim $i$ ich wpływ na ksztattowanie modelu ochrony zdrowia publicznego na ziemiach zaboru pruskiego w XIX w. na przykładzie rejencji bydgoskiej, [w:] B. Płonka-Syroka, A. Syroka (red.), Przełom nowożytny w nauce europejskiej i jego kontekst społecznokulturowy, „Studia z Dziejów Kultury Medycznej”, t. 8, Wrocław 2004. 
Działalność władz miasta oraz towarzystw społecznych w walce z gruźlicą...

Kulak T., Historia Wrocławia. Od twierdzy fryderycjańskiej do twierdzy hitlerowskiej, T. II, Wrocław 2001.

Kuźmińska A., Koncepcja profilaktyki chorób zakaźnych i jej realizacja do końca XIX w., [w:] B. Płonka-Syroka (red.), Człowiek, natura, kultura - studia $z$ historii $i$ antropologii medycyny i farmacji społecznej, „Studia Humanistyczne Wydziału Farmaceutycznego Akademii Medycznej we Wrocławiu”, t. 2, Wrocław 2009.

Kuźmińska A., Walka z epidemiami chorób zakaźnych w Europie w XIX w. ze szczególnym uwzględnieniem gruźlicy, [w:] B. Płonka-Syroka (red.), Człowiek, natura, kultura - studia z historii i antropologii medycyny i farmacji społecznej, „Studia Humanistyczne Wydziału Farmaceutycznego Akademii Medycznej we Wrocławiu”, Wrocław 2010.

Mączyńska K., Mączyński M., Penicyliny. Historia odkrycia i pierwsze zastosowanie, [w:] B. Płonka-Syroka, A. Syroka (red.), Leczyć, uzdrawiać, pomagać. Studia z dziejów kultury medycznej, t. 11, Wrocław 2007.

McMillen W, Discovering Tuberculosis: A Global History, 1900 to the Present, Yale 2015.

Migała M., Rozwój terapii balneoklimatycznej na Górnym Ślasku w aspekcie leczenia gruźlicy (druga połowa XIX i pierwsza połowa XX wieku), Opole 2009.

Moskwa Z., Zarys historii leczenia gruźlicy ptuc, Warszawa 1987.

Nosko J., Zachowania zdrowotne i zdrowie publiczne. Aspekty historyczno-kulturowe, Łódź 2005.

Nowosielska-Sobel J., Sobel G., Dolny Ślask w latach 1918-1945, [w:] W. Wrzesiński (red.), Dolny Ślask. Monografia historyczna, Wrocław 2006.

Okólska H., Wrocławski Samorząd na początku XX w., Wrocław 2004.

Ptaszycka A., Zagospodarowanie Wrocławia w latach 1945-55, [w:] J. Świątecki (red.), Wrocław. Rozwój urbanistyczny, Warszawa 1956.

Ruffie J., Sournia J.C., Historia epidemii. Od dżumy do AIDS, tłum. B.A. Matusiak, Warszawa 1996.

Szubert M., Żyjąc w cieniu śmierci... Kulturowy obraz gruźlicy, Wrocław 2011.

Wójtowicz M., Kliniki Uniwersyteckie - zespót zabudowań wydziału medycznego z lat 1887-1909, [w:] Rozpędowski J. (red.), Architektura Wrocławia Gmachy, T. 4, Wrocław 1998. 
Zielonka T.M., Epidemiologia gruźlicy w Polsce i na świecie w dawnych czasach, [w:] Dusińska H. (red.), Walka z gruźlica u ludzi $i$ zwierzat $w$ Polsce. Stulecie pierwszego polskiego laboratorium pratka, Rudka 1912-2012, Warszawa 2012.

Zwolska Z., Robert Koch twórca bakteriologii chorób zakaźnych, Gdańsk 2006.

\section{Encyklopedie, atlasy}

Harasimowicz J. (red.), Atlas architektury Wrocławia, t. 1, Wrocław 1997.

Harasimowicz J. (red.), Encyklopedia Wrocławia, Wrocław 2006.

Komender J., Mossakowski M.J., Orłowski T., Ostrowski K., Rudowski W., Trzebski A. (red.), Wielki Słownik Medyczny, Warszawa 1996.

Otałęga Z. (red.), Encyklopedia biologiczna, T. 5, Kraków 1998.

Otałęga Z. (red.), Encyklopedia biologiczna, T. 9, Kraków 2000.

Wojnowski J. (red.), Wielka Encyklopedia PWN, T. 5, Warszawa 2001.

Wojnowski J. (red.), Wielka Encyklopedia PWN, T. 9, Warszawa 2002.

\section{Strony internetowe}

Biographicalsketch Camille Guérin (1872-1961), https://www.britannica.com/biography/Camille-Guerin.

\section{Summary \\ Activities of city authorities and social societies in the fight against tuberculosis in Wroclaw in 1919-1933 (selected aspects)}

Activity of social societies, whose main purpose was to combat tuberculosis in the city of Wroclaw during Weimar Republic period, has not been elaborated so far. This is a particularly important issue as it concerns peoples' health and the consequences of untreated tuberculosis diseases. The authorities of Wroclaw city had put much effort to mitigate risk of tuberculosis proliferation. They had an impact on improving the living conditions, creating new hospitals or even special organizations, which main purpose was to fight and control the disease. It is important to mentioned that these organizations made a huge contribution to enlighten society. Also they established new treatment centers, which focused on curing diseased and improving the quality of life through creating new places to live such as Pracze Odrzańskie estate. 